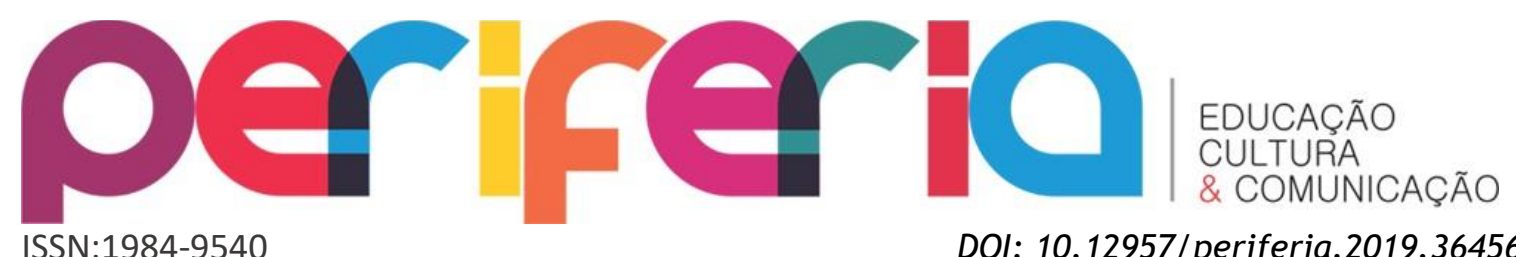

\title{
SEMANA ACADÊMICA DO CURSO DE PEDAGOGIA: MEMES EM PROL DA INFÂNCIA PARA CRITICAR O CONSUMISMO
}

\author{
Edna Araujo dos Santos de Oliveira ${ }^{1}$ \\ Universidade do Estado de Santa Catarina \\ Roseli Zen Cerny ${ }^{2}$ \\ Universidade Federal de Santa Catarina
}

\section{Resumo:}

Esse artigo apresenta as experiências desenvolvidas no primeiro semestre de 2018, na III Semana Acadêmica da Pedagogia, com acadêmicos do curso de Pedagogia a Distância do Centro de Educação a Distância, da Universidade do Estado de Santa Catarina. Os encontros presenciais aconteceram na modalidade de oficinas que foram ofertadas pelos professores da casa e seu objetivo nuclear foi o de aprofundar a discussão em torno dos temas Contemporâneos da Educação Infantil, tendo em vista explorar com os(as) educandos(as) uma compreensão crítica do ato estudar e do fazer docente na modalidade a distância. Neste sentido, as oficinas foram planejadas em alguns momentos didáticos: reunião coletiva, sala de aula no ambiente virtual de aprendizagem Moodle e encontro presencial em cada polo/turma, cujos desdobramentos em termos de ensino-aprendizagem são detalhados neste texto. 0 foco do artigo é sobre a oficina "Consumo e Infância", cujo trabalho se desdobrou no espectro da cultura digital e a avaliação da aprendizagem foi aferida com a teoria de Recouer na elaboração de memes educativos. Acreditamos que o relato exposto nesse artigo possa ser útil para a divulgação do trabalho que tem sido realizado na universidade, mostrando que a educação a distância pode ser feita com qualidade e tem um grande potencial a ser desenvolvido.

Palavras-chave: Pedagogia, Infância e Consumo, Cultura Digital, Memes

\footnotetext{
${ }^{1}$ Pedagoga, Mestre em Educação pela Universidade do Estado de Santa Catarina - UDESC, Doutoranda em Educação pelo PPGE da Universidade Federal de Santa Catarina - UFSC, Professora Colaborado do Centro de Educação a Distância na Universidade do Estado de Santa Catarina, Pesquisadora Colaboradora Observatório de Práticas Curriculares Itinera - UFSC. E-mail: ednaaoliv@gmail.com

${ }^{2}$ Doutora, Pedagoga, professora do Programa de Pós-Graduação em Educação da Universidade Federal de Santa Catarina - UFSC, Vice-Diretora do Centro de Ciências da Educação - UFSC, Vice-Líder do Observatório de Práticas Curriculares Itinera - UFSC.
} 


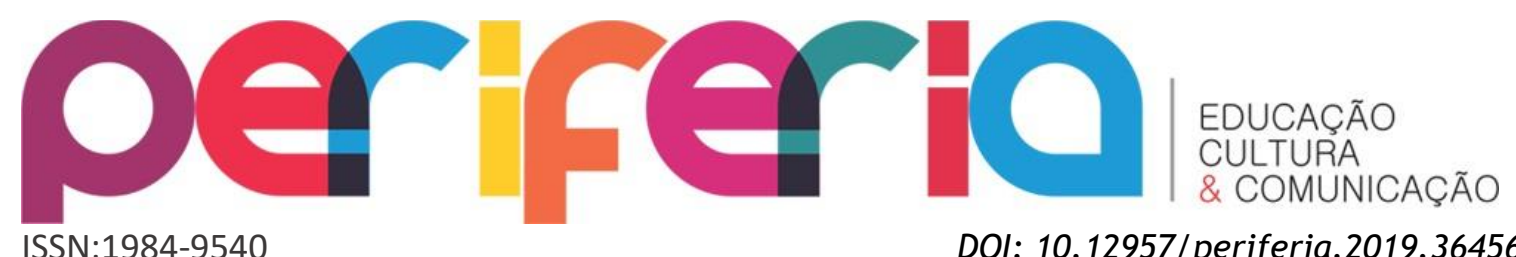

\title{
ACADEMIC WEEK OF THE COURSE OF PEDAGOGY: MEMES IN PROL OF INFANCY VERSUS CONSUMMISM
}

\begin{abstract}
:
This report presents the experiences developed in the first semester of 2018, in the Third Academic Week of Pedagogy, with academics of the Distance Education course at the Center for Distance Education, State University of Santa Catarina. The faceto-face meetings took place in the form of workshops that were offered by the teachers of the house and its nuclear objective was to deepen the discussion around the contemporary themes of early childhood education, in order to explore with the students a critical understanding of studying and doing faculty in distance mode. In this sense, the workshops were planned in some didactic moments: collective meeting, classroom in the virtual learning environment Moodle and face-to-face meeting in each pole / class, whose developments in terms of teaching-learning are detailed in this text. The focus of the report will be on the workshop "Consumption and Childhood", whose work unfolded in the spectrum of the digital culture and the evaluation of learning was measured with the theory of Recouer with the elaboration of educational memes. We believe that this report can be useful for the dissemination of the work that has been carried out in the university, showing that distance education can be done with quality and has a great potential to be developed.
\end{abstract}

Keywords: Pedagogy, Childhood and Consumption, Digital Culture, Memes 


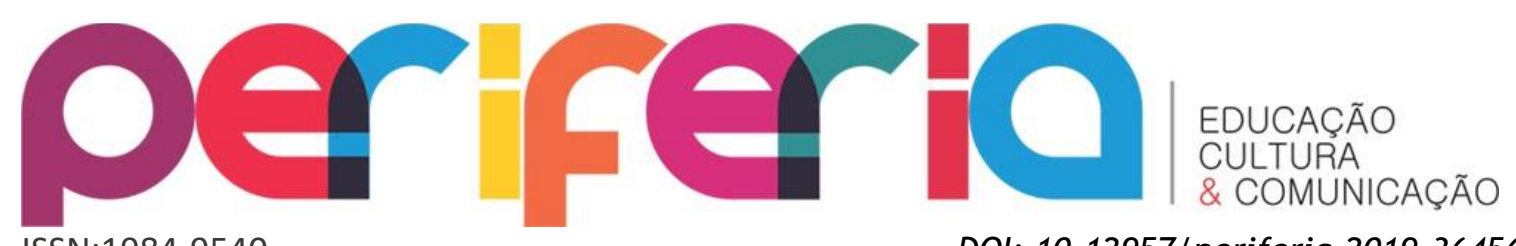

ISSN:1984-9540

DOI: $10.12957 /$ periferia.2019.36456

\section{SEMANA ACADÉMICA DEL CURSO DE PEDAGOGÍA: MEMES EN PROL DE LA INFANCIA PARA CRITICAR EL CONSUMISMO}

\section{Resumen:}

Este relato presenta las experiencias desarrolladas en el primer semestre de 2018, en la III Semana Académica de la Pedagogía, con académicos del curso de Pedagogía a Distancia del Centro de Educación a Distancia, de la Universidad del Estado de Santa Catarina. Los encuentros presenciales se realizaron en la modalidad de talleres que fueron ofrecidos por los profesores de la casa y su objetivo nuclear fue el de profundizar la discusión en torno a los temas Contemporáneos de la Educación Infantil, con el fin de explorar con los (as) educandos (as) una comprensión crítica del acto estudiar y del hacer docente en la modalidad a distancia. En este sentido, los talleres fueron planeados en algunos momentos didácticos: reunión colectiva, aula en el ambiente virtual de aprendizaje Moodle y encuentro presencial en cada polo / clase, cuyos desdoblamientos en términos de enseñanza-aprendizaje se detallan en este texto. El foco del relato será sobre el taller "Consumo e Infancia", cuyo trabajo se desdobló en el espectro de la cultura digital y la evaluación del aprendizaje fue evaluada con la teoría de Recouer con la elaboración de memorias educativas. Creemos que este relato puede ser útil para la divulgación del trabajo que se ha realizado en la universidad, mostrando que la educación a distancia puede ser hecha con calidad y tiene un gran potencial a ser desarrollado.

Palabras clave: Pedagogía, Infancia y Consumo, Cultura Digital, Memes 


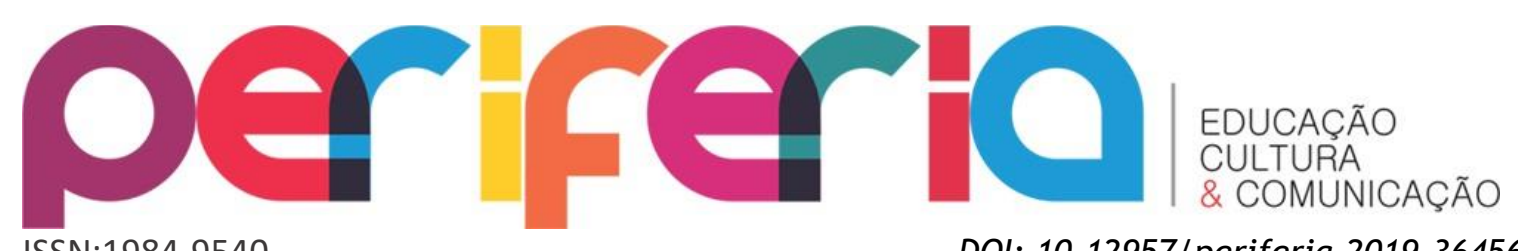

ISSN:1984-9540

DOI: $10.12957 /$ periferia.2019.36456

\section{Introdução}

Com sede em Florianópolis, o Centro de Educação a Distância - CEAD, é um centro que desenvolve atividades em nível de Ensino de Graduação, Pesquisa e PósGraduação e Extensão. No âmbito da graduação, desde 2011 oferece o Curso de Pedagogia a Distância em convênio com o Sistema Universidade Aberta do Brasil (UAB), tendo, no ano de 2015, graduado mais de 600 pedagogos, sendo que em 2017, a instituição passa a ofertar mais dois cursos de graduação na modalidade a distância: Curso de Licenciatura em Biologia e Curso de Licenciatura em Informática. Atualmente o centro atende aproximadamente 160 acadêmicos, distribuídos na $1^{\text {a }}$, $3^{\mathrm{a}}$ e $7^{\mathrm{a}}$ fases.

Com ênfase nas Tecnologias de Informação e Comunicação, o curso de Pedagogia a Distância do CEAD - UDESC também aponta como princípio norteador a "Formação teórica interdisciplinar sobre o fenômeno educacional e seus fundamentos filosóficos, históricos, políticos e sociais, bem como sobre os conteúdos inerentes à Educação Infantil, aos Anos Iniciais do Ensino Fundamental”. (UDESC, 2009, p.9).

A formação teórica interdisciplinar é prevista na composição dos eixos curriculares, e o PPC orienta, como uma das finalidades do curso, que as práticas pedagógicas estejam "subordinadas aos princípios de unidade e interdisciplinaridade dos conteúdos dos programas, à ação integrada dos docentes, e à relação entre teoria e a prática" (UDESC, 2009, p.9).

Desde 2014 o Núcleo Docente Estruturante e Coordenação de Curso vêm dialogando sobre como seria possível expandir as discussões e efetivações de propostas interdisciplinares. Foi então que foi criada a figura do Coordenador de Fase, cujo papel principal é o de articular com as equipes da fase, propostas interdisciplinares entre disciplinas afins, bem como temáticas interdisciplinares que sejam discutidas por cada fase ao longo do semestre. Sobre essa questão, temos alguns relatos (GARCEZ; CARVALHO; RIPA, 2015) que elucidam algumas das propostas interdisciplinares que já foram concretizadas até o momento. 


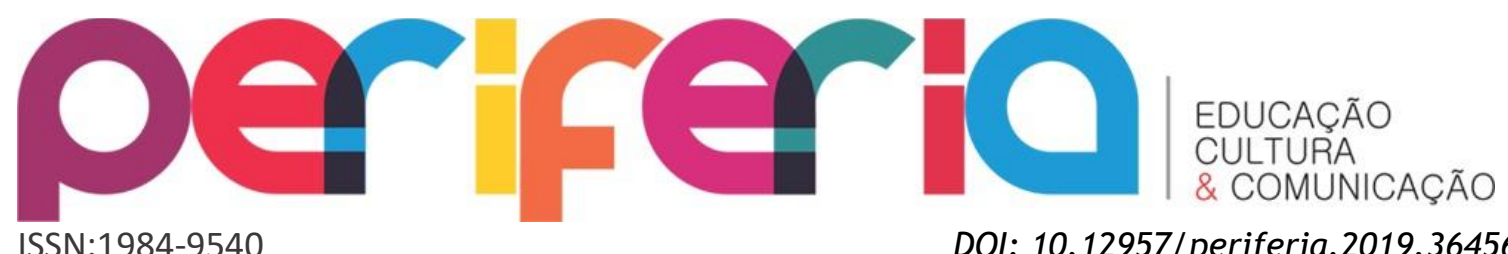

Em 2018/01, após discussão com os professores do curso e o reconhecimento de que os momentos de interação dos acadêmicos do curso de Pedagogia a Distância ocupa um lugar privilegiado na vida e no percurso acadêmico e profissional dos educadores, a temática elegida para Semana Acadêmica da Pedagogia foi "Temas Contemporâneos da Educação Infantil" com alguns subtemas para serem trabalhados pelos professores em oficinas presenciais, sendo eles:

Interações e Brincadeiras na Infância; A BNCC e o Currículo para a Educação Infantil; Infância e Interações Tecnológicas; Saúde e Infância (incluindo no debate temas como medicalização da infância e alimentação), Mídias e Infância (cinema, jogos e programas de TV), Novos Pressupostos da Literatura Infantil e Consumo e Infância, sendo esta última o tema da oficina que será relatada.

Os professores do curso participaram das reuniões que antecederam o Seminário, problematizaram os temas elegidos que destacam a centralidade dos referidos estudos e ação docente voltada para o debate das temáticas no processo de formação de educadores e assim, escolheram sob qual temática desenvolveriam sua oficina presencial.

A oficina em destaque neste artigo é a oficina "Consumo e Infância", oficina produzida e ministrada por nós, cujo pressuposto abordado foi o aprofundamento da discussão em torno deste tema contemporâneo, no intuito de avançar na discussão de problemáticas urgentes das infâncias a partir do que já conhecemos dos relatos e vivências dos acadêmicos nas escolas (excesso de personagens nos materiais escolares, alimentação motivada por comerciais de televisão, desejo por brinquedos vinculados a vídeos dispostos na internet, entre outros) e do que presenciamos constantemente enquanto telespectadores nos ambientes virtuais que frequentamos, nos programas que assistimos na TV e no que observamos e vivenciamos em nosso entorno - experiência sobre a qual nos debruçamos nos parágrafos seguintes. 


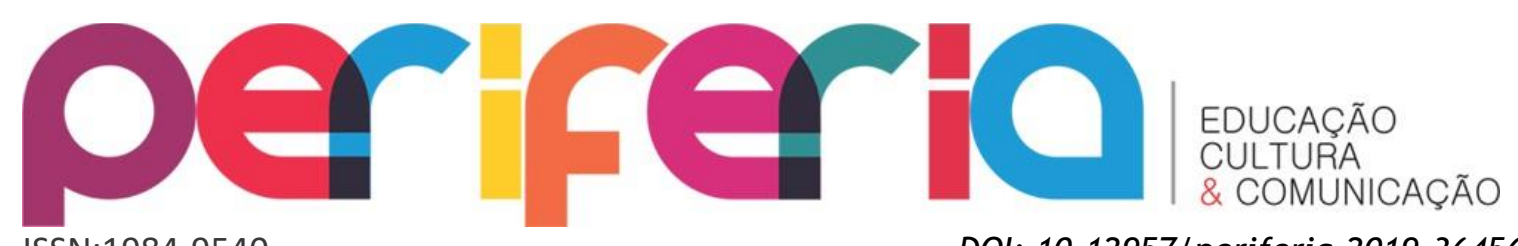

ISSN:1984-9540

DOI: $10.12957 /$ periferia.2019.36456

\section{A proposta desenvolvida na oficina Consumo e Infância}

No primeiro semestre de 2018 em que aconteceu a III Semana Pedagógica do curso de Pedagogia, a instituição contava com um total de 300 alunos, distribuídos em 9 turmas/polos no Estado de Santa Catarina. O planejamento da III Semana Pedagógica iniciou ainda no mês de fevereiro de 2018, em reunião com os colegas docentes com o objetivo de organizar o cronograma do semestre e conhecer os conteúdos e equipe docente de cada disciplina, visando à busca por atividades interdisciplinares.

Cabe mencionar que a interdisciplinaridade aqui defendida, ancora seu sentido na inserção do trabalho do educador de forma coletiva na condição de abertura científica e tecnológica, de modo a desenvolver uma prática docente de pesquisa que seja investigativa, descentralizada e com fronteiras que ultrapassem os cerceamentos curriculares, os cerceamentos das disciplinas.

A síntese interdisciplinar, mencionada é apenas um passo prévio para definir o que é próprio da Pedagogia, ou seja, investigação da realidade educativa, visando, mediante conhecimentos científicos, filosóficos e técnico-profissionais, a explicitação de objetivos e formas de intervenção metodológica e organizativa relacionados com a transmissão/assimilação ativa de saberes. Está ressaltada aí a intencionalidade educativa própria de toda prática social, pois a Pedagogia envolve intervenção humana e, portanto, um comprometimento moral de quem a realiza. (LIBÂNEO, 2001, p.23)

Ou seja, a interdisciplinaridade se torna indispensável, pois nesta condição, o professor-educador trabalha com posicionamento crítico a partir das diretrizes de sua própria disciplina, articulando as diversas possibilidades interdisciplinares a considerar o currículo, o trabalho coletivo dos colegas, as demandas sociais, articuladas com os saberes de outros profissionais com vistas á inovação.

Com relação às temáticas da III Semana Pedagógica, desde o início do planejamento aventou-se a possibilidade de ter uma temática envolvendo temas contemporâneos. Em um primeiro momento os professores manifestaram interesse em trabalhar sobre a atual reforma curricular (BNCC), porém, diante da realidade vivenciada e as polêmicas geradas e narradas constantemente pelos nossos 


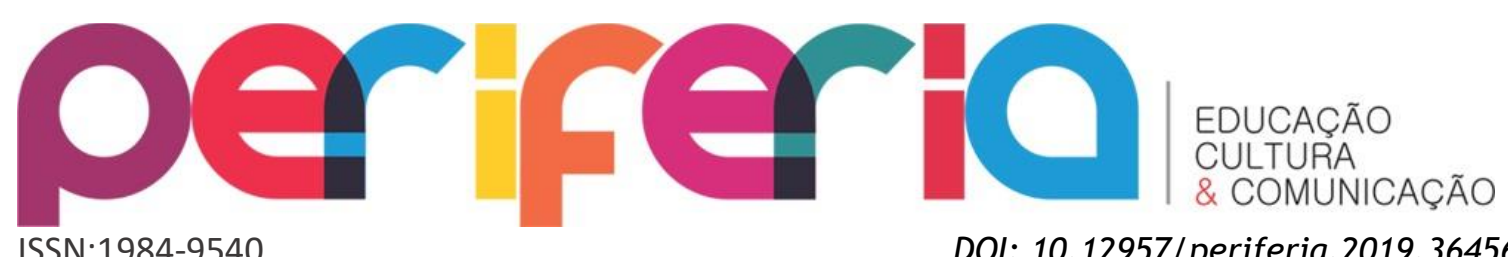

ISSN:1984-9540

DOI: $10.12957 /$ periferia.2019.36456

acadêmicos em tempos de Cultura Digital, em que se possui grande acesso à informação, às redes sociais, decidiu-se ampliar as possibilidades temáticas com temas urgentes para a infância e que os acadêmicos já haviam pontuado a necessidade de tais abordagens na universidade, já que o consumo está atrelado aos sujeitos desde que estão nos ventres de suas genitoras.

Num ambiente social centrado em buscas consumistas e em empreendimentos individualistas, o fascínio pelas mercadorias e o impulso compulsivo e vicioso de comprar tornam-se as principais virtudes a serem promovidas e cultivadas nas crianças desde seu nascimento. (ESPERANÇA; RIBEIRO, 2014, p. 763)

A oficina teve início com explanação geral a respeito da temática, apresentação de temas e notícias polêmicas disponíveis nas redes, como por exemplo, alguns vídeos de Youtubers-mirins e debate acerca da exposição das infâncias e os impactos sociais do consumismo infantil.

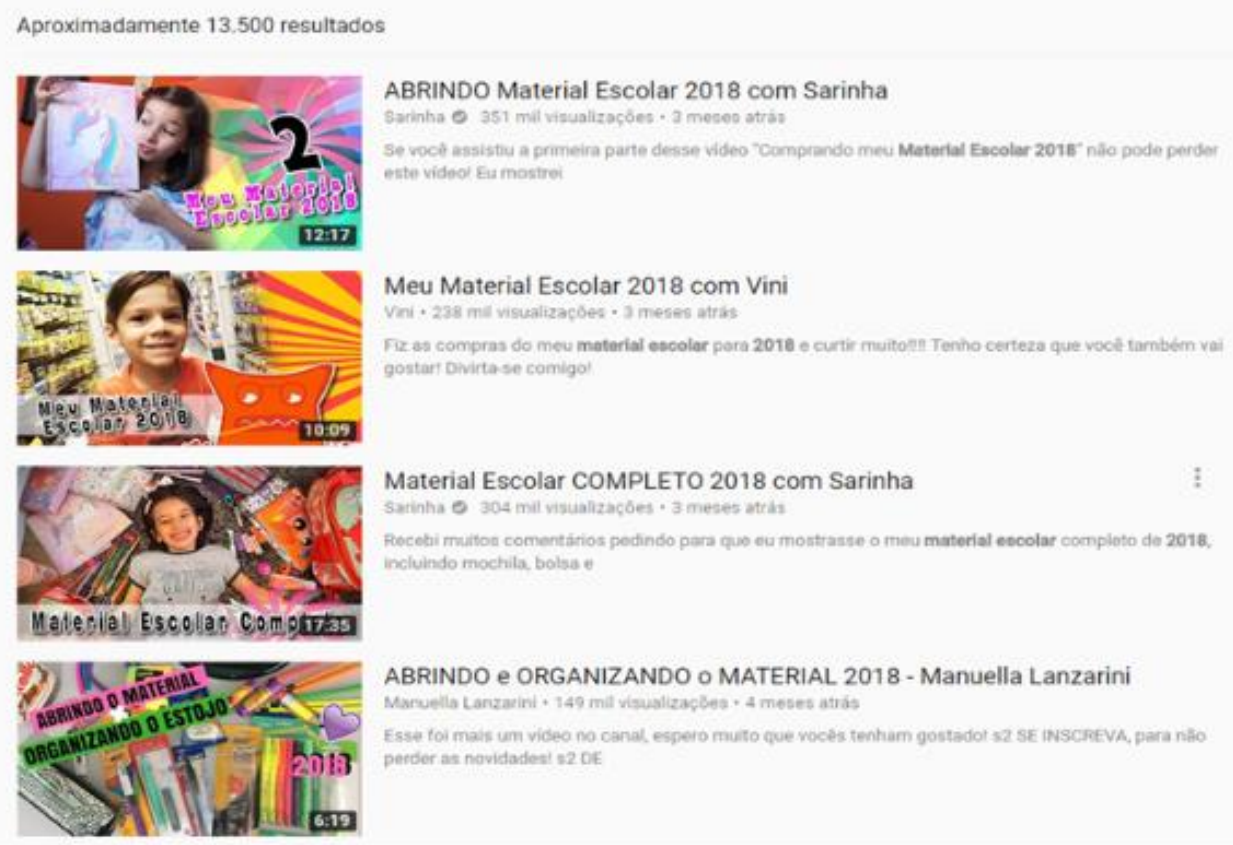

Fonte: Print Screen realizado na página do YouTube com o termo de busca: Material escolar 2018.

A partir da problematização de alguns destes vídeos dispostos no YouTube e o debate do fenômeno unpacking (desembalar), em que as crianças mostram em seus 


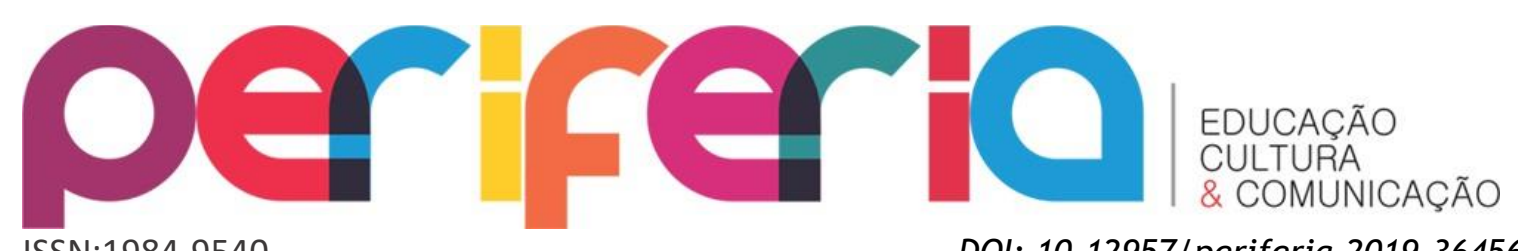

ISSN:1984-9540

DOI: $10.12957 /$ periferia.2019.36456

vídeos caseiros os presentes recebidos de lojas e comerciantes ou até mesmo presenteados pelos próprios pais, houve o consenso sobre a intenção dos mesmos: o de propagar! As crianças figuram como atores de comerciais, induzindo à compra dos produtos por eles expostos, alarmando o desejo de consumo escondido na narrativa de uma apresentação inocente de um presente recebido naquele momento.

Segundo pesquisa da World Childhood Foundation ${ }^{3}$, 65\% das meninas exploradas sexualmente declaram usar o dinheiro conseguido para comprar celular, tênis ou roupas. A Organização Brasileira Criança e Consumo complementa a pesquisa informando que outros fatores nocivos ao desenvolvimento da infância também se relacionam com o consumismo infantil, como a obesidade infantil, erotização precoce, consumo precoce de tabaco e álcool, estresse familiar, banalização da agressividade e violência, entre outras.

Afirmam também que a publicidade veiculada na televisão é apenas um dos fatores que contribuem para o consumismo infantil. A TNS/InterScience ${ }^{4}$, instituto de pesquisa que atua em mais de 70 países, divulgou dados em setembro de 2007 que evidenciaram outros fatores que influenciam as crianças brasileiras nas práticas de consumo. Elas sentem-se mais atraídas por produtos e serviços que sejam associados a personagens famosos, brindes, jogos e embalagens chamativas. A opinião dos amigos também foi identificada como uma forte influência. E a reprodução deste comportamento está no cotidiano das escolas, está na pauta das infâncias contemporâneas.

Transmitimos um trecho do documentário "Criança, a alma do negócio" e então o debate foi direcionado para os impressionantes números sobre o consumismo infantil, como por exemplo, o tempo médio que as crianças passam em frente à TV e outros dispositivos eletrônicos como celulares e tablets (nesse caso, 5 horas por dia); sobre comerciais voltados exclusivamente para alimentos processados para crianças com o uso de personagens de desenhos, filmes e personalidades do YouTube em suas embalagens, além de dados sobre as crianças que preferem passear nos shoppings centers ao invés de frequentarem parques em áreas abertas.

\footnotetext{
${ }^{3}$ Disponível em:http://www.childhood.org.br/. Acesso em 29/01/2019.

${ }^{4}$ Disponível em: http://criancaeconsumo.org.br/consumismo-infantil/. Acesso em 29/01/2019.
} 


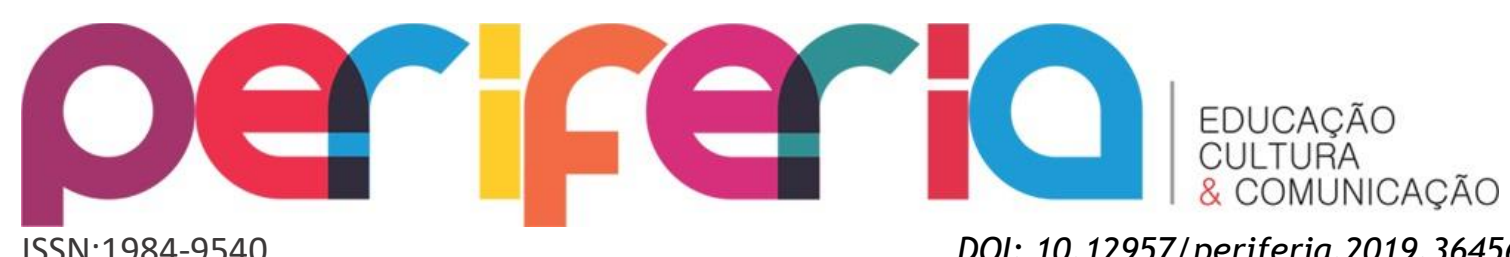

Avançando nas discussões, ficou definido que os acadêmicos aproveitariam o fluxo da internet, que semeia informações, fakenews e também sementes para o consumo e o desafio foi lançado: "Como a Escola pode agir, no intuito de pensar e materializar alternativas para discutir a temática "consumismo na infância" e conscientizar acerca deste problema?"

Diante do desafio lançado, a proposta foi de que os acadêmicos criassem um texto viral ou um meme para responder o questionamento lançado pelo desafio. Esses momentos são detalhados no subitem abaixo.

\subsection{Memes e educação}

Ao mencionarmos o termo "meme", direcionamos o pensamento para a veia cômica, irônica, para o humor. Porém, o termo foi criado pelo Zoólogo Richard Dawkins em 1976 ao escrever sua teoria sobre o processo de transmissão cultural humana. Vem daí o nome empregado aos "memes" que conhecemos na web, que são imagens ou pequenos vídeos, que se espalham, se ressignificam e se reformulam de maneira incansável pelos meios de comunicação e entre as pessoas.

O conceito de meme foi cunhado por Richard Dawkins (1976), que discutia a cultura como produto da replicação de ideias, que ele chamou memes [...]. A partir de uma abordagem evolucionista, Dawkins compara a evolução cultural com a evolução genética, onde o meme, o "gene" da cultura, se perpetua através de seus replicadores, as pessoas. (RECUERO, 2009, p. 123)

O meme auxilia na articulação da escrita, da leitura e da reflexão. Foge das técnicas formais de estudos escolares, suscitando compreensão de múltiplas funções sociais da leitura no aluno (interpretação, conhecimento do fator abordado, ironia, sagacidade de linkar as imagens com o código escrito, entre outras possibilidades) e acaba por cumprir uma função política, ajudando a questionar estereótipos e posturas de temas necessários de serem abordados na contemporaneidade, além de promover identificações.

Ainda sobre a difusão dos "memes" na internet, pode-se dizer que ela está relacionada com "questões de filiação e adesão aos sentidos 


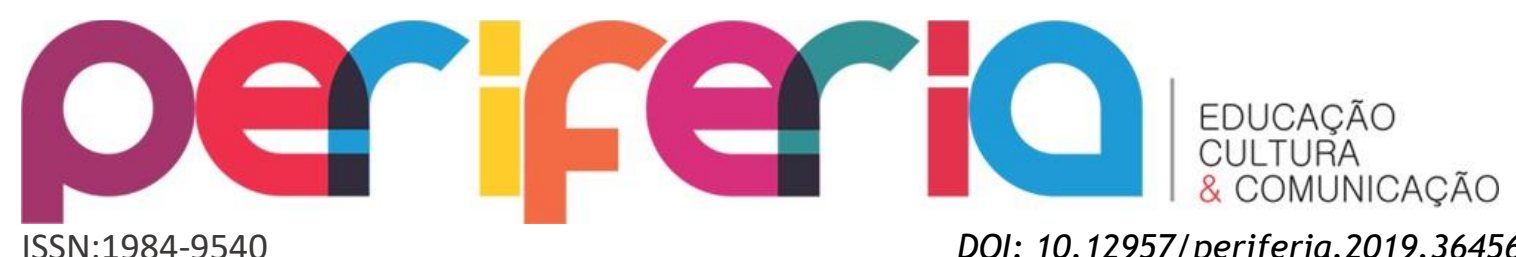

expressos pelo conteúdo dos "memes" - ou seja, as formações ideológicas presentes nas formações discursivas destes fragmentos. (SOUZA, 2001, p. 134)

É certo que existe uma diferenciação de sentido entre o "meme" de quem o criou e de quem o recebe, ainda que a ideia chega ao receptor e cria um laço ideológico positivo ou negativo que faz sentido para aquele ator social, mas não somente a ele. Partindo desse sentido, porque não criar memes educacionais para auxiliar na conscientização de um determinado assunto para a sociedade? Porque não utilizar dessa narrativa para avaliar, provocar, pensar conteúdos e temas da educação?

O filósofo Ricoeur (1994) estabeleceu uma ideia de mimese que escapa ao seu conceito original de imitação. Ao construir narrativamente algo que a própria experiência humana já prefigura, mesmo não havendo uma originalidade inventiva plena, o narrador não imita, antes atua dinamicamente no seu processo de narrar. 0 filósofo discerne, então, "a mimese (imitação, representação) da atividade mimética mais que imitar ou representar, a narrativa exige um processo ativo de produção, processo esse dinâmico, que pressupõe ainda o agenciamento dos fatos, conferindo um caráter de atividade, ação". (RICOEUR, 1994, p.98)

Dessa forma, a narrativa é desenvolvida mediante três dimensões, que ele intitula tríplice mimese: mimese I (pré-figuração), II (configuração) e III (reconfiguração). Mimese I é o que referencia a composição narrativa, mimese II é o que ele vai chamar de mimesecriação e mimese III, mimese-invenção, o ponto de chegada, o lugar da reconfiguração. (RICOEUR, 1994, p.98)

É mediante a atividade mimética que as narrativas estudantis aqui serão avaliadas, posto que uma análise estrutural não abarcaria as subjetividades imbricadas nessas três etapas de construção da narrativa. Os elementos de análise começarão pela atividade referenciada pelo meme (mimese I), passando pela atividade dos relatos construídos em sala de aula (mimese II) até a sua reconfiguração ensaiada na análise aqui realizada e também na posterior correção avaliativa do professor. 


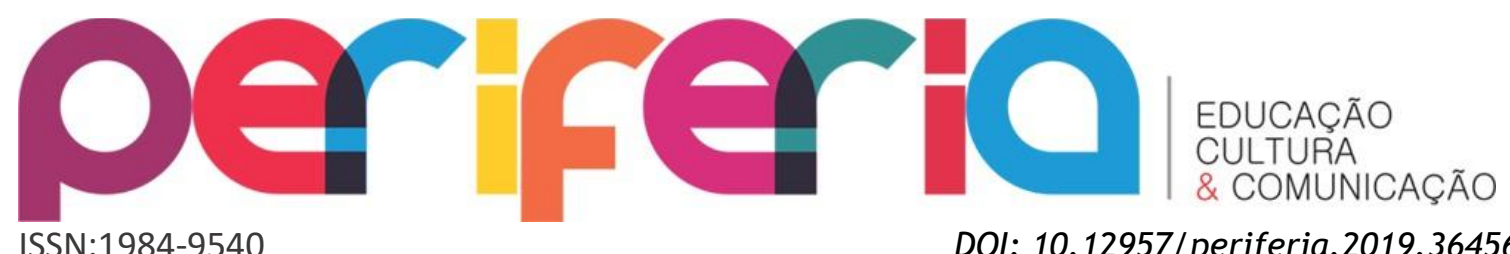

A ideia da utilização dos memes permitiu maior interatividade entre os sujeitos participantes e, ao passo em que a provocação era inicialmente discutida pelas duplas que criariam o meme, outros acadêmicos puderam participar propondo questionamentos, tirando dúvidas sobre a criação e viabilidade do mesmo, solicitando maiores esclarecimentos sobre este ou àquele ponto menos claro na concepção da criação de memes para o objetivo proposto, articulando com o foco da oficina - conscientizar sobre os perigos do consumismo infantil.

\subsection{Os embates de criação dos memes}

Considerando as possibilidades disponíveis na internet $e$ após a contextualização da possibilidade do uso dos memes para fins didáticos, optou-se por trabalhar em duplas e utilizamos o site "Gerador de Memes" 5 , visto que os acadêmicos não se sentiram à vontade para eleger ou selecionar fotografias de livre escolha. $\mathrm{O}$ acesso foi realizado nos computadores do polo, embora alguns acadêmicos tenham preferido acessar de seus próprios celulares. Os memes foram enviados para uma sala virtual no Moodle, já que este espaço contribui “(...) para a melhoria dos processos de coordenação, organização e gestão da disciplina, consequentemente para melhorar a qualidade social inerente ao processo educativo, incentivar o estabelecimento de mecanismos de interação e trocas colaborativas entre os sujeitos da disciplina". (BORGES, 2012, p. 10).

Partindo desse pressuposto, o grupo dos oficineiros optou por fazer deste recurso o canal de criação dos memes educacionais conscientizadores que encerrou o debate para o cumprimento do desafio proposto inicialmente: "Como a Escola pode agir, no intuito de pensar e materializar alternativas para discutir a temática "consumismo na infância" e conscientizar acerca deste problema?"

Estivemos envolvidos(as) com a tarefa de pensar, planejar e (com)partilhar memes que nos forçou a questionar os limites estreitos de nosso poder de síntese e de trabalhar temática tão séria com determinada dose de humor. 0 momento para

\footnotetext{
${ }^{5}$ Disponível em: http://geradormemes.com/criar. Acesso em jul/2018.
} 


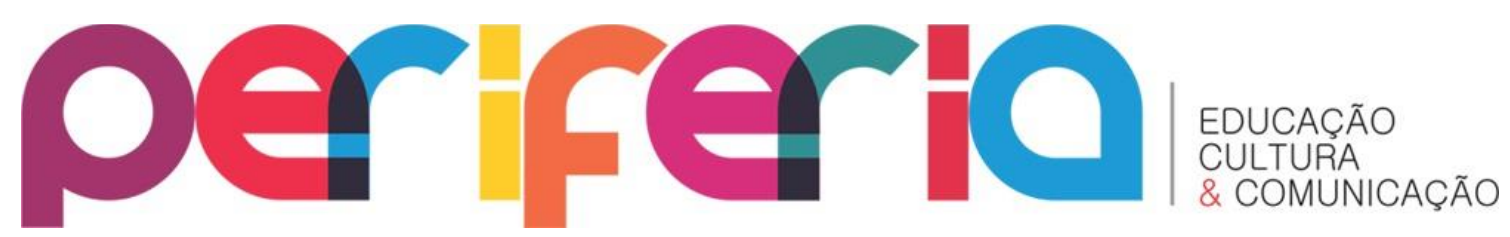

ISSN:1984-9540

DOI: $10.12957 /$ periferia.2019.36456

a criação dos memes foi, antes de tudo, um lugar de encontro no qual uma mesma temática ganhou tonalidades e contornos diferentes provocados pelas histórias de vida, de consumo inconsciente muitas vezes fomentado pelas redes sociais e de formação de cada um(a) dos(as) acadêmicos que promoveram os mais diversos diálogos enquanto executavam a tarefa.

Relatos dos acadêmicos a respeito de suas experiências com alunos do ensino fundamental e infantil acerca de consumo de alimentos industrializados, excesso de personagens nos materiais escolares e disputa de posse de brinquedos da moda foram frequentes na oficina. Os relatos vieram acompanhados de reflexões e cobranças para a universidade que não os prepara para essas lides cotidianas, eis a importância de proporcionar momentos interdisciplinares como estes, seja em forma de oficinas ou debates. Dados que foram apresentados à universidade ao final do evento.

Muitos acadêmicos não sabiam da existência do documentário assistido, das organizações que agem em favor da infância e na conscientização sobre o consumo. Perguntas instigantes e necessárias ajudaram a compor um mosaico de histórias de vida, de escolarização, lembranças carregadas muitas vezes de preocupação, outras de indignação. Narrativas sendo "revividas" a partir de uma leitura outra, sustentada pelos ensinamentos práticos da vivência proporcionada pela III Semana Pedagógica em uma tarefa que procurou estimular o movimento construído pelos próprios acadêmicos na tessitura do debate sobre Infância e Consumismo que thes serviu como inspiração.

E entre um relato e outro, a criação dos memes educativos para "viralizar" a conscientização sobre os problemas no consumismo na infância foram materializados. 


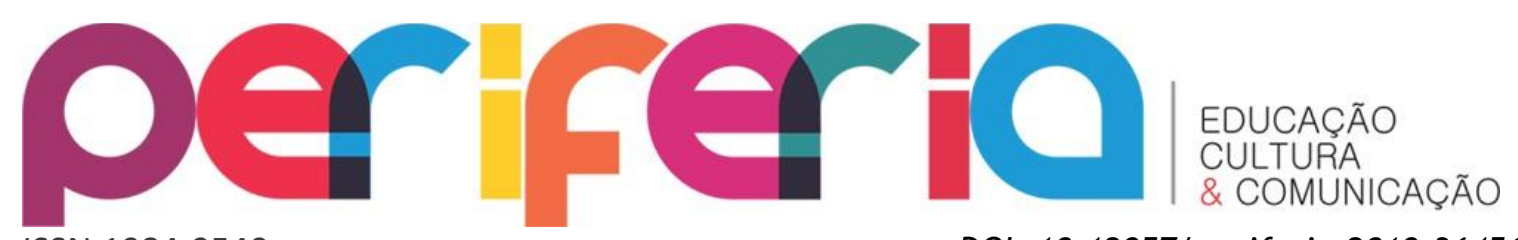

ISSN:1984-9540

DOI: $10.12957 /$ periferia.2019.36456

\subsection{Avaliação do processo de criação e as relações de aprendizagens conquistadas}

Partindo do que se propunha na avaliação das produções dos acadêmicos sobre os memes produzidos na Oficina Infância e Consumo na III Semana Pedagógica da Pedagogia no CEAD-UDESC, consideramos as três dimensões propostas por RICOEUR (1994, p.77) na "tríplice mimese": Mimese I - pré-figuração; mimese II - configuração e mimese III - invenção.

Nessa perspectiva, consideramos que a mimese I, constituída pela fase de préfiguração, ou seja, a composição da narrativa, foi realizada e apropriada nos momentos iniciais da oficina, com a fala da docente acerca da temática, todos os dados e estatísticas apresentados, conteúdos assistidos e visitados para o encadeamento da sensibilização dos acadêmicos oficineiros acerca do debate apresentado.

A mimese II, que trata da configuração, trata da mimese-criação, do exercício de colocar em prática o que se está pensando sobre a temática abordada. Trata do exercício de síntese que traduzirá a mensagem que gostariam de levar aos seu interlocutores. Diga-se de passagem, a etapa mais difícil do trabalho, visto que os acadêmicos participantes da oficina, sentiram-se surpreendidos com a possibilidade de criar seu próprio meme viral e isso os carregou de inseguranças.

A ideia inicial era que eles selecionassem o conteúdos abordados e as imagens a serem utilizadas de maneira livre. Porém, diante das dificuldades apresentadas, e por força do tempo da oficina, apresentamos o "gerador de memes" e, com isso, sentiram-se mais à vontade para pensar no conteúdo de impacto/humor com vistas à problematização e conscientização, sem o tempo investido da seleção de imagem.

Por fim, na mimese III ou mimese-invenção, que trata do ponto de chegada, do lugar da reconfiguração dos saberes trabalhados nas etapas anteriores, que pudemos perceber a evolução da criação da narrativa proposta e o resultado atingido em suas criações: 

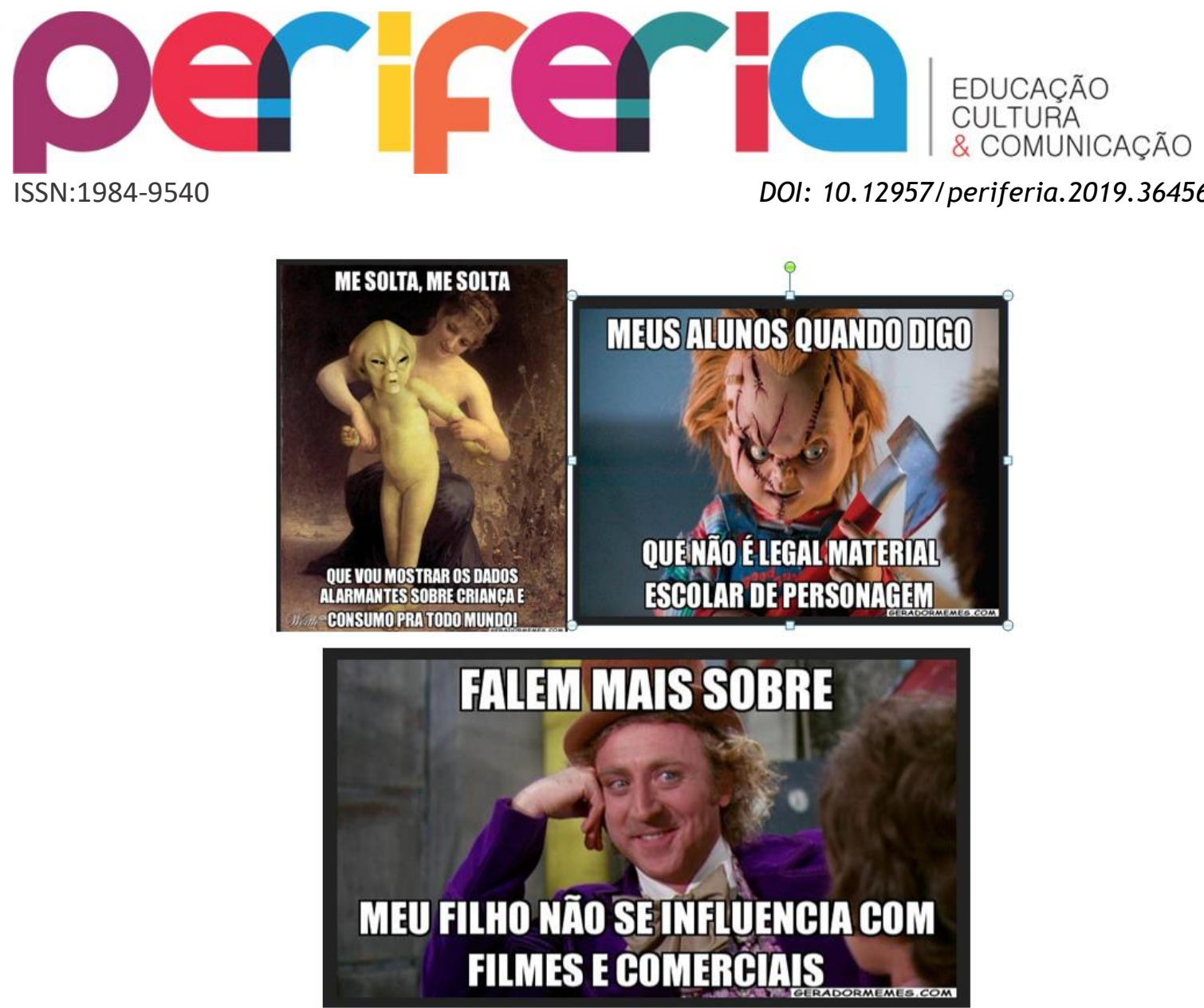

Fonte: Memes criados pelos acadêmicos do polo de Blumenau, participantes da III Semana Pedagógica da Pedagogia

0 olhar atento às infâncias fez surgir uma nova possibilidade, nela foram propostas relações entre a perspectiva de conteúdo informativo, conscientização e conhecimento. Essa perspectiva vem ao encontro do pensamento filosófico de Ricoeur quando afirma que

a atividade mimética é mais que imitar ou representar, é uma narrativa conquistada à guisa de compreensão perspicaz de onde se pretende chegar e exige um processo ativo e dinâmico de produção que pressupõe a compreensão dos fatos sociais, conferindo um caráter de atividade, ação plenamente conscientes. (RICOEUR, 1994, p.60)

Inspirados nas reflexões desta oficina e apoiados nas leituras indicadas, os acadêmicos compartilharam experiências de produção de memes em suas redes sociais particulares e estavam ansiosos para saberem da repercussão das mesmas.

Por fim, a oficina foi encerrada, em horário posterior ao combinado devida a empolgação dos participantes com o debate, com a atividade e com a avaliação deste 


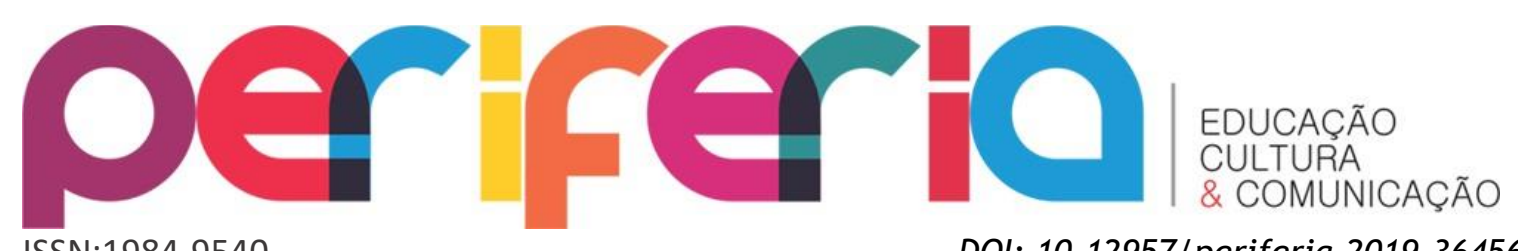

ISSN:1984-9540

DOI: $10.12957 /$ periferia.2019.36456

trabalho, que servirá de subsídio para novas proposições pedagógicas, bem como para continuidade dos trabalhos em outras oficinas e porque não em disciplinas.

\section{Considerações finais}

A temática interdisciplinar concretizada nos três momentos descritos: videoconferência coletiva, sala no Moodle e encontros presenciais, foi um projeto desenvolvido pela $2^{\text {a }}$ fase do Curso de Pedagogia a Distância do Centro de Educação a Distância - CEAD, da Universidade do Estado de Santa Catarina - UDESC. A proposta foi bem aceita pelos professores, coordenação pedagógica e acadêmicos, dado último constatado principalmente pelo expressivo número de participações dos educandos, muitas vezes em número maior que suas intervenções nas próprias disciplinas.

A oficina mencionada neste referido artigo, que deveria ter a duração de quatro horas conforme combinado com a instituição, teve seu tempo extrapolado para quatro horas e quarenta minutos em função dos pedidos dos acadêmicos. É um dado muito significativo, considerando o total de alunos do curso e as condições de participação presencial, que sabemos que dependem de inúmeros fatores como disponibilidade de participar em dia não obrigatório de atividade formal acadêmica, distância das residências do polo, entre outras.

A escolha por essa ferramenta didática de gerador de memes para a materialização do trabalho realizado na oficina Infância e Consumismo possibilitou aos acadêmicos a expressão de situações pessoais e profissionais partindo de temática urgente a ser debatida em todos os contextos sociais. Entre as participações dos acadêmicos e as mediações dos professores, totalizaram cerca de trinta e quatro participações no fórum virtual "Memes a favor da Infância contra o consumismo".

$\mathrm{Na}$ avaliação da proposta, todos os acadêmicos-oficineiros participaram. A expressividade dessa participação demonstra o compromisso dos acadêmicos com sua formação, por não se tratar de atividade obrigatória e tampouco resultante de notas.

Essa experiência formativa deixa, para nós professores, a sensação de um projeto interdisciplinar bem pensado, desenvolvido e avaliado pelos alunos. Já 


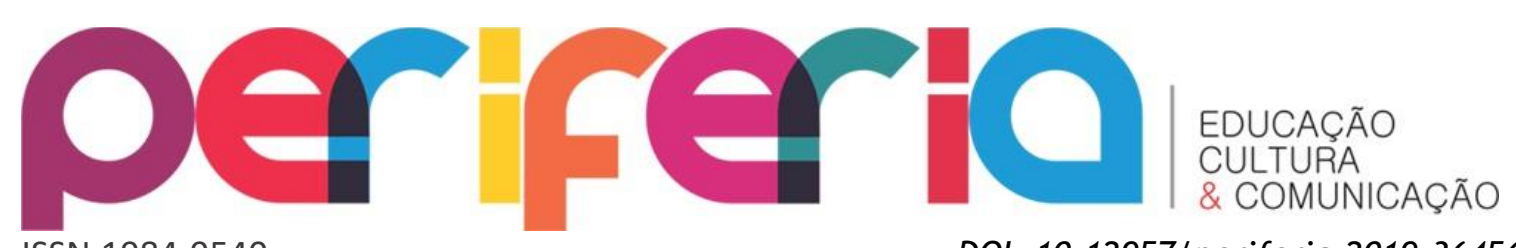

ISSN:1984-9540

DOI: 10.12957/periferia.2019.36456

ansiamos pelos planejamentos das próximas oficinas, em que essa mesma temática será trabalhada com novas equipes, olhares e proposições, sem perder de vista o olhar que as práticas coletivas requerem, a adequação dos saberes teóricos em consonância a viabilização de estratégias práticas para problemáticas educacionais cotidianas.

\section{Referências:}

BORGES, Marilene. A. F. $O$ uso da web 2.0 em cursos de educação a distância: criando novas possibilidades. In: II CONGRESSO INTERNACIONAL TIC E EDUCAÇÃO, 2012, LISBOA. II CONGRESSO INTERNACIONAL TIC E EDUCAÇÃO, 2012.

BRASIL. Base Nacional Comum Curricular. Brasília: Ministério da Educação, 2017.

CASTELLS, Manuel. A galáxia da internet: reflexões sobre a internet, os negócios $e$ a sociedade. Rio de Janeiro: Jorge Zahar, 2003.

DAWKINS, Richard. O Gene Egoísta. Tradução de Rejane Rubino. São Paulo. Companhia das Letras. 2007

ESPERANÇA, Joice Araujo; RIBEIRO, Paula Costa. Comprar, querer e desejar: problematizando as narrativas de crianças dos anos iniciais . Revista Perspectiva, Florianópolis, v. 32, n. 2, 759-790, maio/ago. 2014.

FONTANELLA, Fernando Israel. 0 que é um meme na Internet? Proposta para uma problemática da memesfera. III Simpósio Nacional ABCiber - Dias 16, 17 e 18 de Novembro de 2009 - ESPM/SP - Campus Prof. Francisco Gracioso.

GARCEZ, A. F. ; RIPA, Roselaine. A interdisciplinaridade na Educação a Distância: DISCUTINDO PRÁTICAS PEDAGÓGICAS NO CURSO DE PEDAGOGIA. In: XII Congresso Brasileiro de Ensino Superior a Distância e I Congresso Internacional de Ensino Superior a Distância (CIESUD), 2015, Salvador. Anais do ESUD 2015. Salvador: UNEAD - UNEB, 2015. v. 1. p. 1-10.

IBGE - Instituto Brasileiro de Geografia e Estatística. Tabela 1383: taxa de alfabetização das pessoas de 10 anos ou mais de idade por sexo, 2010. Disponível em: <http:// www.sidra.ibge.gov.br/cd/cd2010universo. asp? $0=5 \& \mathrm{ti}=\mathrm{P}>$. Acesso em: 06 nov. 2018. 


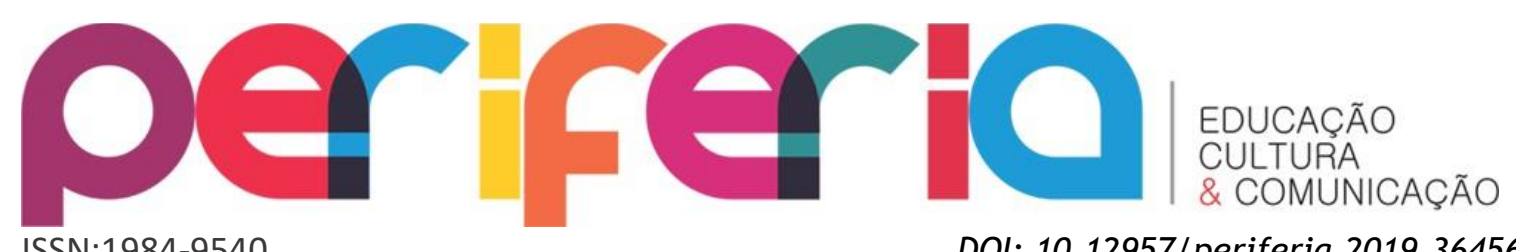

LIBÂNEO, José Carlos. Pedagogia e pedagogos: inquietações e buscas . Educar, Curitiba, n. 17, p. 153-176. 2001. Editora da UFPR. Acesso em 29 jan. 2019.

PACHECO, José. TEDxUNISINOS: Experiências Inovadoras na Educação. Disponível em: < https://www.youtube.com/watch?v=reOEnY8jkjo >. Acesso em: 06 jun. 2016.

RECUERO, Raquel. Redes sociais na internet. Porto Alegre: Sulina, 2009.

RICOEUR, Paul. Tempo e narrativa, v. I. Campinas: Papirus, 1994.

UNIVERSIDADE DO ESTADO DE SANTA CATARINA (UDESC). Centro de Educação a Distância. Projeto Pedagógico do Curso de Pedagogia a Distância. Florianópolis, 2009.

SOUZA, Carlos Fabiano de. Memes: formações discursivas que ecoam no ciberespaço. Vértices, Campos dos Goytacazes, volume 15, n 1, p. 127-148, janeiro a abril de 2013 